\title{
Effects of green tea polyphenols, insulin-like growth factor I and glucose on developmental competence of bovine oocytes
}

\author{
Zhengguang Wang ${ }^{1}$, Chunquan $\mathrm{Fu}^{2}$, Songdong $\mathrm{Yu}^{1}$ \\ ${ }^{1}$ College of Animal Science of Zhejiang University; Key Laboratory for Molecular Animal Nutrition, Ministry of Education, Hang Zhou, 310029, \\ P. R. China. \\ 2 Jinhua College of Vocation and Technology.
}

\begin{abstract}
The present study examined the effects of green tea polyphenols (GTP), insulin-like growth factor-I (IGF-I) and glucose on oocyte in vitro maturation, subsequent embryo development and blastocyst quality in bovine. Cumulus-oocyte complexes (COC) were aspirated from the ovaries and cultured in synthetic oviduct fluid supplemented with MEM amino acids (SOFaa) media supplemented with one of the following supplements: GTP $(0,10,15$ and $20 \mu \mathrm{M})$, IGF-I $(0,50,100$ and $150 \mathrm{ng} / \mathrm{mL})$ or glucose $(0,1.5,5.6$ and $20 \mathrm{mM})$ for $24 \mathrm{~h}$. The results showed that oocytes cultured in media supplemented with $15 \mu \mathrm{M}$ GTP, $100 \mathrm{ng} / \mathrm{mL}$ IGF-I and $5.6 \mathrm{mM}$ glucose, in separate experiments, have higher cleavage and blastocyst rates compared with oocytes cultured in media without or with other concentration of GTP, IGF-I and glucose. Then these three substances with the concentration above were added together into SOFaa media and constituted a modified medium (Modified SOFaa). The COC were cultured in control SOFaa media and modified SOFaa media, respectively. The results showed that modified SOFaa media increased the intracellular glutathione concentration of matured oocytes, blastocyst rates and total cell numbers and cell numbers of inner cell mass per blastocyst compared with the control. Supplementing of GTP, IGF-I and glucose synchronously to maturation media can increase the intracellular GSH concentration of oocytes after in vitro maturation, and improve the embryo development and blastocyst quality in bovine.
\end{abstract}

Key Words: blastocyst quality, embryo development, in vitro culture, in vitro maturation

\section{Introduction}

In vitro maturation (IVM) of bovine oocytes, followed by in vitro fertilization (IVF) and subsequent embryo culture, is an important tool used for both research and commercial purposes. However, rates of blastocyst formation for oocytes matured and fertilized in vitro are lower than those obtained with in vivo production systems (Lonergan \& Fair, 2008). Low blastocyst formation by in vitro matured oocytes indicates that current oocyte maturation systems do not adequately support either nuclear and/or cytoplasmic maturation. Therefore, the improvement of oocyte maturation system by defining IVM conditions more similar to the in vivo environment is very important for increasing the blastocyst formation. Glucose is an essential energy substrate for mammalian cells and has been reported to improve the nuclear maturation of cow, mouse and pig oocytes (Hashimoto et al., 2000a; Herrick et al., 2006; Wongsrikeao et al., 2006). Several previous studies have shown that addition of IGF-I to in vitro media promotes oocytes maturation and also affects their subsequent in vitro development (Quetglas et al., 2001; Stefanello et al., 2006). Recently, researchers have demonstrated that in vitro bovine embryo productions are improved by treatments with GTP during IVM of oocytes (Wang et al., 2007).

However, the effects of GTP, IGF-I and glucose combined supplementation on the nuclear and cytoplasmic maturation of bovine oocytes, subsequent embryo development and blastocyst quality have not been studied. Therefore, the objective of the present study was to evaluate the effects of GTP, IGF-I and glucose for IVM of bovine oocytes on the oocyte glutathione content, oocyte nuclear and cytoplasmic maturation (measured as the capacity of subsequent embryo development), embryonic development (cleavage and blastocyst rates) and blastocyst quality.

\section{Material and Methods}

All chemicals and media were purchased from Sigma Chemical Co. (St. Louis, MO, USA), unless otherwise indicated. The GTP used in this study contained $99 \%$ catechin derivatives, among which the major components were 50\% (-)-epigallocatechin gallate (EGCG), 22\% (-)-epicatechin gallate, 18\% (-)-epigallocatechin and 10\% (-)-epicatechin. The average molecular weight of the GTP was calculated according to the percentage of the major component. 
The in vitro production of embryos was carried out as previously described by Rizos et al. (2002) with minor modifications. Briefly, cumulus-oocyte complexes (COC) were obtained by aspirating 2 to $6 \mathrm{~mm}$ follicles from the ovaries of cows collected at abattoir. The COC with compact cumulus cells were washed three times in Hepes buffered Tyrode's medium supplemented with $0.3 \%$ bovine serum albumin (BSA) and in maturation medium, respectively. Groups of $10 \mathrm{COC}$ were placed in $50 \mu \mathrm{L}$ maturation medium, covered with mineral oil and then incubated at $38.5{ }^{\circ} \mathrm{C}$ in $5 \% \mathrm{CO}_{2}$ in air with saturated humidity for 24 hours. The basic maturation medium was SOFaa, which consisted of modified synthetic oviduct fluid (SOF) supplemented with MEM non-essential amino acids, BME essential amino acids, $1.5 \mathrm{mM}$ glucose, $1 \mathrm{mM}$ glutamine, $1 \mu \mathrm{g} / \mathrm{mL}$ porcine FSH, $5 \mu \mathrm{g} / \mathrm{mL}$ ovine $\mathrm{LH}$ and $4 \mathrm{mg} / \mathrm{mL}$ BSA. The SOF medium used in this study was based upon the original formulation (Tervit et al., 1972) with subsequent modifications (Gardner et al., 1994). To evaluate the nuclear maturation, after 24 hours of culture, oocytes were completely denuded by vortex shaking and placed on glass slides in small drops. The slides were fixed in methanol:acetic acid fixative (1:3) solution for a minimum of 24 hours. The oocytes were stained with $1 \%$ aceto-orcein and examined under a phase contrast microscope. Oocytes at the M II stage with the first polar body were classified as fully matured. Maturation rate is defined as the ratio of oocytes at the M II stage and total oocytes.

The in vitro fertilization was performed with frozenthawed sperm from one bull at a concentration of $2 \times 10^{6}$ spermatozoa $/ \mathrm{mL}$. Frozen bull semen was thawed and prepared by a swim-up procedure (Parrish et al., 1986). Gametes were co-incubated for 22 hours at $38.5{ }^{\circ} \mathrm{C}$ under an atmosphere of $5 \% \mathrm{CO}_{2}$ in air with maximum humidity in dishes with $10 \mathrm{COC}$ and $50 \mu \mathrm{L}$ of Tyrode's albumin lactate pyruvate medium (TALP). Approximately $20 \mathrm{~h}$ post insemination (hpi), presumptive zygotes were denuded by gentle vortexing and washed four times in PBS and once in SOFaa medium. Embryo culture took place in SOFaa under mineral oil in a humidified atmosphere of $5 \% \mathrm{CO}_{2}$, $7 \% \mathrm{O}_{2}$ at $38.5{ }^{\circ} \mathrm{C}$. Cleavage and development of embryos to the blastocyst stage were assessed at $48 \mathrm{hpi}$ and $192 \mathrm{hpi}$, respectively.

For the GSH assay, a sample of matured oocytes was stripped off surrounding cumulus cells by repeated pipetting with a narrow-bore glass pipette in Hepes-TALP and washed three times in $\mathrm{Mg}^{2+} / \mathrm{Ca}^{2+}$-free PBS, containing $1 \mathrm{mg} / \mathrm{mL}$ polyvinylpyrrolidone. Pools of 50 oocytes in $10 \mu \mathrm{L}$ of PBS were placed in microtubes, frozen at $-20{ }^{\circ} \mathrm{C}$ and thawed at room temperature. This procedure was repeated three times. Complete cell disruption was achieved by repeated aspiration using a narrow- bore pipette. Samples were then mixed with $0.1 \mathrm{M}$ phosphate buffer containing

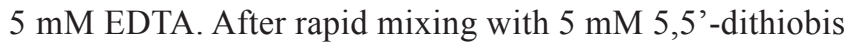
2-nitrobenzoic acid, 1 IU of glutathione reductase and $1.1 \mathrm{mM}$ NADPH, the increase in absorbance at $412 \mathrm{~nm}$ from $30 \mathrm{~s}$ to $5 \mathrm{~min}$ was measured using a double-beam spectrophotometer (Beckman Mod. 35, Irvine, CA). Blanks containing $10 \mu \mathrm{L}$ of PBS without oocytes were similarly processed and no detectable amounts of GSH-GSSG were found. The total GSH content in the oocyte was calculated from a standard curve prepared using GSH (Tietze, 1969; Takahashi et al., 1993). In the conditions at the laboratory where the analyses took place, the assay limit was 25 pmol of GSH-GSSG.

The differential staining of inner cell mass (ICM) and trophoectoderm cells (TE) associated with TUNEL was used to assess the Day 8 blastocyst quality and the apoptosis conditions as previously described (FouladiNashta et al., 2005). Briefly, embryos were permeablized using $0.2 \%(\mathrm{v} / \mathrm{v})$ solution of Triton X-100 in SOF containing $4 \mathrm{mg} / \mathrm{mL}$ BSA for $20 \mathrm{~s}$. Embryos were then washed and incubated in $30 \mu \mathrm{g} / \mathrm{mL}$ propidium iodide (stains the TE cells red) for 10 min followed by washing and fixation in 4\% paraformaldehyde containing $30 \mu \mathrm{g} / \mathrm{mL}$ Hoescht 33342 (stains all cells blue). Apoptotic cells were then detected by TUNEL labeling using a FITC-conjugated in situ cell death detection kit, fluorescein (Roche, Penzberg, Germany) according to the instructions of the manufacturer. Briefly, embryos were permeabilized by incubating in $0.1 \%(\mathrm{v} / \mathrm{v})$ Triton X-100 for $5 \mathrm{~min}$ and incubated in the kit reagent (1:10 dilution of the terminal deoxynucleotidyl transferase solution in label solution) in a humid chamber for $45 \mathrm{~min}$ at $37^{\circ} \mathrm{C}$. Embryos were washed and immediately mounted on glass slides and examined under an epifluorescent microscope.

In experiment 1 , oocytes were matured in SOFaa media supplemented with the different concentrations of GTP $(0,10,15$ and $20 \mu \mathrm{M})$, respectively. In experiment 2, IGF-I $(0,50,100$ and $150 \mathrm{ng} / \mathrm{mL}$, respectively) were added in SOFaa media to optimize the supplemental concentration of IGF-I during IVM of bovine oocytes. In experiment 3, oocytes were matured in SOFaa media in the presence of $0,1.5,5.6$ and $20 \mathrm{mM}$ glucose, respectively. In experiment 4, GTP $(15 \mu \mathrm{M})$, IGF-I (100 ng/mL) and glucose $(5.6 \mathrm{mM})$ were added together into SOFaa media based on the results of experiment 1-3 and constituted a modified media (Modified SOFaa). Oocytes were cultured in SOFaa (control) and modified SOFaa, respectively. In experiment 4 , matured oocytes were fixed to assay the intracellular 
GSH concentration and then Day 8 blastocysts were used to investigate the effects of modified SOFaa media on the embryo quality and apoptosis conditions.

All experiments were replicated three times. Data were analyzed by analysis of variance (ANOVA) of the software SAS (Statistical Analysis System, version 6.13). Comparisons were considered significantly different if $\mathrm{P}<0.05$.

\section{Results}

The maturation rates of oocytes were higher in 10 and $15 \mu \mathrm{M}$ GTP treatments than in the $20 \mu \mathrm{M}$ GTP treatment $(\mathrm{P}<0.05$; Table 1). Supplementation of media with three GTP concentrations during IVM improved the cleavage rate compared with control $(\mathrm{P}<0.05)$. Compared with no addition and supplementation of $10 \mu \mathrm{M}$ GTP, the inclusion of $15 \mu \mathrm{M}$ and $20 \mu \mathrm{M}$ GTP during IVM increased the blastocyst rate $(\mathrm{P}<0.05)$.

The inclusion of 100 and $150 \mathrm{ng} / \mathrm{mL}$ IGF-I during IVM increased the maturation rates of oocytes compared with control and $50 \mathrm{ng} / \mathrm{mL}$ IGF-I $(\mathrm{P}<0.05$; Table 2$)$. The presence of $100 \mathrm{ng} / \mathrm{mL}$ IGF-I during IVM increased cleavage and blastocyst rate compared with $50 \mathrm{ng} / \mathrm{mL}$ IGF-I and control
$(\mathrm{P}<0.05)$. No improvements in the cleavage and blastocyst rate were found when $150 \mathrm{ng} / \mathrm{mL}$ IGF-I were added to maturation medium in comparison with the $100 \mathrm{ng} / \mathrm{mL}$ IGF-I treatment.

Supplementation of media with glucose during IVM improved maturation of bovine oocytes compared with control (Table 3). The oocytes matured in media supplemented with $5.6 \mathrm{mM}$ glucose had higher cleavage and blastocyst rate than oocytes matured with $1.5 \mathrm{mM}$ glucose and control $(\mathrm{P}<0.05)$. However, a further increase in glucose concentration from 5.6 to $20 \mathrm{mM}$ resulted in a decrease in cleavage and blastocyst rate $(\mathrm{P}<0.05)$.

The modified SOFaa media did not improve the maturation rate and cleavage rate compared with control (Figure 1). The modified media increased the blastocyst rates on day 8 of in vitro insemination compared with the control media $(\mathrm{P}<0.05)$. The modified media increased the intracellular GSH concentration within the oocytes when compared to control media ( $\mathrm{P}<0.05$; Figure 2$)$. The total cell numbers and ICM cell numbers of blastocysts were significantly higher in the modified SOFaa group than the control $(\mathrm{P}<0.05$; Table 4). However, the apoptosis rates of blastocysts had no difference between the modified SOFaa group and the control $(\mathrm{P}>0.05)$.

Table 1 - Effects of GTP on maturation in vitro and development of bovine oocytes

\begin{tabular}{lcccc}
\hline Concentration of GTP $(\mu \mathrm{M})$ & Oocytes $(\mathrm{n})$ & Maturation rate $(\%)$ & Cleavage rate $(\%)$ & Blastocyst rate $(\%)$ \\
\hline 0 & 111 & $69.4 \pm 2.3 \mathrm{ab}$ & $45.9 \pm 1.5 \mathrm{a}$ & $19.7 \pm 0.8 \mathrm{a}$ \\
10 & 109 & $76.1 \pm 4.1 \mathrm{~b}$ & $60.8 \pm 3.2 \mathrm{~b}$ & $18.4 \pm 1.7 \mathrm{a}$ \\
15 & 117 & $77.0 \pm 3.3 \mathrm{~b}$ & $64.1 \pm 2.6 \mathrm{~b}$ & $28.1 \pm 1.5 \mathrm{~b}$ \\
20 & 120 & $65.9 \pm 2.7 \mathrm{a}$ & $60.3 \pm 2.0 \mathrm{~b}$ & $25.8 \pm 0.9 \mathrm{~b}$ \\
\hline
\end{tabular}

Different letters within same column indicate significant difference $(\mathrm{P}<0.05)$.

GTP - green tea polyphenols.

Table 2 - Effects of IGF-I on maturation and development of bovine oocytes

\begin{tabular}{lccc}
\hline Concentration of IGF-I $(\mathrm{ng} / \mathrm{mL})$ & Oocytes $(\mathrm{n})$ & Maturation rate $(\%)$ & Cleavage rate $(\%)$ \\
\hline 0 & 121 & $60.4 \pm 3.7 \mathrm{a}$ & $39.9 \pm 2.9 \mathrm{a}$ \\
50 & 108 & $62.0 \pm 2.1 \mathrm{a}$ & $40.7 \pm 2.4 \mathrm{a}$ \\
100 & 113 & $74.3 \pm 3.0 \mathrm{~b}$ & $61.1 \pm 3.1 \mathrm{~b}$ \\
150 & 112 & $75.1 \pm 2.7 \mathrm{~b}$ & $21.4 \pm 1.4 \mathrm{~b}$ \\
\hline
\end{tabular}

Different letters within same column indicate significant difference $(\mathrm{P}<0.05)$.

IGI-F - insulin-like growth factor I.

Table 3 - Effects of glucose on maturation and development of bovine oocytes

\begin{tabular}{|c|c|c|c|c|}
\hline Concentration of glucose (mM) & Oocytes (n) & Maturation rate $(\%)$ & Cleavage rate $(\%)$ & Blastocyst rate $(\%)$ \\
\hline 0 & 97 & $36.1 \pm 1.7 \mathrm{a}$ & $21.6 \pm 2.9 \mathrm{a}$ & $11.3 \pm 1.9 \mathrm{a}$ \\
\hline 1.5 & 113 & $65.6 \pm 5.1 \mathrm{~b}$ & $41.5 \pm 3.1 \mathrm{~b}$ & $19.5 \pm 1.4 b$ \\
\hline 5.6 & 109 & $72.5 \pm 3.5 b$ & $54.1 \pm 4.3 \mathrm{c}$ & $27.4 \pm 2.5 c$ \\
\hline 20 & 102 & $69.8 \pm 2.8 b$ & $40.2 \pm 1.0 \mathrm{~b}$ & $12.7 \pm 0.7 \mathrm{a}$ \\
\hline
\end{tabular}

Different letters within same column indicate significant difference $(\mathrm{P}<0.05)$. 


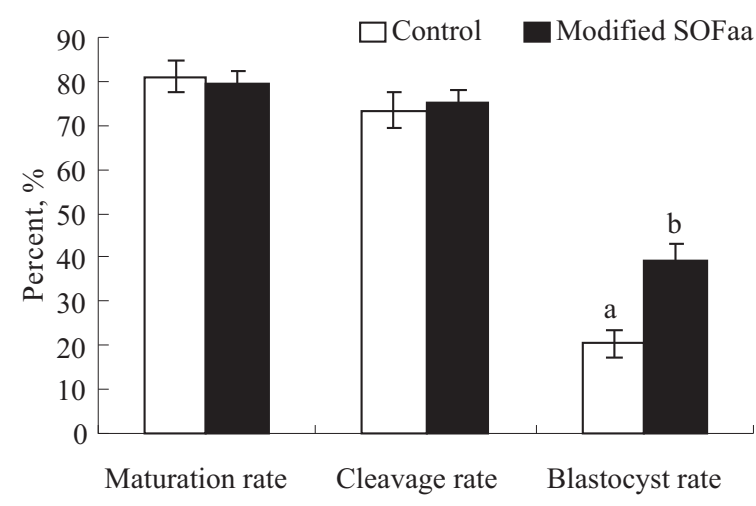

Oocytes matured in SOFaa media as the control.

Values represent means \pm standart error.

Bars with different superscripts are statistically different $(\mathrm{P}<0.05)$.

SOFaa - synthetic oviduct fluid supplemented with MEM amino acids.

Figure 1 - Effects of modified SOFaa media on maturation and development of bovine oocytes.

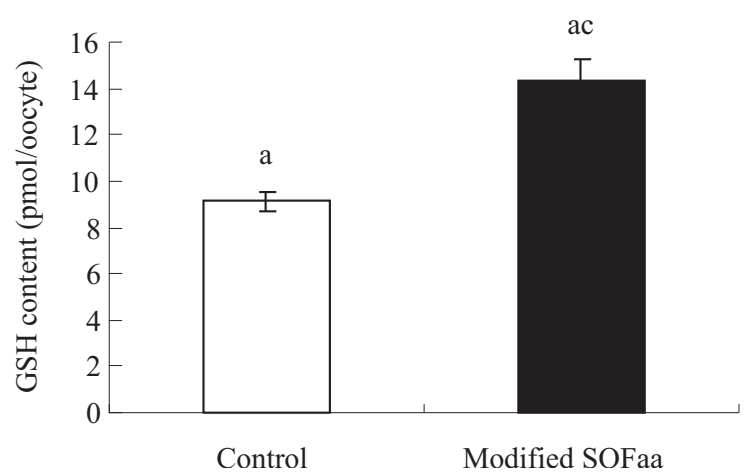

Oocytes matured in SOFaa media as the control.

Values represent means \pm standart error.

Bars with different superscripts are statistically different $(\mathrm{P}<0.05)$.

GSH - glutathione; SOFaa - synthetic oviduct fluid supplemented with MEM amino acids.

Figure 2 - Effects of modified SOFaa media on the intracellular GSH in bovine oocytes.

Table 4 - Embryo quality and apoptosis following in vitro fertilization of bovine oocytes matured with modified SOFaa media or control media

\begin{tabular}{|c|c|c|c|c|c|}
\hline Media & Embryo (n) & Total cell number $(\mathrm{n})$ & Inner cell mass (n) & Trophoectoderm cells (n) & Apoptosis rate $(\%)$ \\
\hline Control & 21 & $89.3 \pm 4.7 \mathrm{a}$ & $21.5 \pm 1.3 \mathrm{a}$ & $68.4 \pm 2.1$ & $4.4 \pm 1.1$ \\
\hline Modified SOFaa & 23 & $113.4 \pm 6.3 b$ & $30.7 \pm 4.9 b$ & $81.9 \pm 5.6$ & $3.6 \pm 0.7$ \\
\hline
\end{tabular}

Different letters within same column indicate significant difference $(\mathrm{P}<0.05)$.

Apoptosis rate is defined as the ratio of the apoptotic cell number and total cell number.

SOFaa - synthetic oviduct fluid supplemented with MEM amino acids

\section{Discussion}

The main finding of this study was that GTP, IGF-I and glucose supplemented synchronously during IVM improve the subsequent developmental competence of embryos. This improvement in developmental competence of oocytes may be partly due to increase of intracellular GSH concentration of matured oocytes and improvement of the quality of blastocysts.

The GTP have strong antioxidant activity (Higdon \& Frei, 2003) and are potent scavengers of ROS (reactive oxygen species), such as superoxide, hydrogen peroxide, hydroxyl radicals and nitric oxide (Schroeder et al., 2003). The results of experiment 1 showed that treatment with $15 \mu \mathrm{M}$ GTP during IVM culture enhanced the developmental competence of bovine oocytes. However, a further increase in the concentration of GTP from 15 to $20 \mu \mathrm{M}$ did not improve the blastocyst rate. These findings were consistent with previous reports (Wang et al., 2007). In agreement with thse observations, it has been stated that supplementation of lower EGCG concentration $(10 \mu \mathrm{g} / \mathrm{mL})$ during IVF significantly increased the fertilization rate, while higher EGCG concentration $(25 \mu \mathrm{g} / \mathrm{mL})$ decreased the percentage of fertilized oocytes (Spinaci et al., 2008). Yavari et al. (2010) also demonstrated that the treatment with higher concentrations of EGCG $(10$ and $50 \mu \mathrm{M})$ during IVC is apparently harmful for the in vitro development of porcine parthenotes.

The results of experiment 2 demonstrated that IGF-I at a dose of 100 or $150 \mathrm{ng} / \mathrm{mL}$ stimulated nuclear maturation of cumulus-enclosed oocytes. The addition of IGF-I during oocyte maturation not only helped in achieving nuclear maturation but also influenced the cytoplasmic maturation and improved early embryonic development. These findings were consistent with previous reports (Pawshe et al., 1998) showing that IGF-I enhanced embryonic cleavage rate and development in bovine when added to the oocyte maturation medium. Although the reasons for this enhancement were unknown, the previous study suggested that IGF-I increased oestradiol production by the theca granulosa cells in serumfree culture (Shores et al., 2000). Furthermore, it was indicated that IGF-I acts as an anti-apoptotic factor during bovine oocyte maturation (Wasielak \& Bogacki, 2007). The biological effects of IGF-I were mediated by its interaction 
with the IGF type I receptor and modulated by IGF binding proteins (Jones \& Clemmons, 1995). Thus, the addition of IGF-I beyond the optimum concentration $(100 \mathrm{ng} / \mathrm{mL}) \mathrm{did}$ not improve the embryo development in this study.

The results of experiment 3 indicated that sufficient glucose is required for oocytes to obtain developmental competence during the maturation period. The beneficial effect of glucose supplementation in the IVM medium may be due to their ability to speed up the progression of nuclear maturation (Iwata et al., 2004). The results from this study also demonstrated that excessive glucose during oocyte maturation impairs the developmental competence. In agreement with the results of experiment 3 , Hashimoto et al. (2000b) reported that the COC cultured in substantially high glucose concentrations (10-28 $\mathrm{mM}$ glucose) compromised the blastocyst development compared with COC cultured in low to moderate glucose levels $(1.5 \mathrm{mM}$ or $5.6 \mathrm{mM}$ glucose).

The present study demonstrated first the effects of GTP, IGF-I and glucose supplementing synchronously to maturation media on improving the development of bovine in vitro embryo. This improvement in the developmental competence of oocytes may be partly due to increase of intracellular GSH concentration after IVM of oocytes. Furthermore, the results of experiment 4 showed that modified SOFaa increase the total cell number and cell number of ICM in Day 8 blastocysts. One approach to evaluate blastocyst quality is to count the cell numbers of the ICM and the TE, as well as total cells of the embryo by differential staining. It is well documented that total cell numbers and numbers of ICM cell can be regarded as valuable indicators of cattle embryo viability (Knijin et al., 2003; Koo et al., 2002). Thus, the current result suggested that supplementing GTP, IGF-I and glucose to maturation media synchronously can improve the quality of bovine blastocysts. In agreement with our observation, it has been suggested that the proportion of ICM cells in blastocysts is crucial for later post-implantation development (Iwasaki et al., 1990) and an increase in total cell number in blastocysts correlates with improved embryo viability (van Soom et al., 1997).

\section{Conclusions}

Supplementing of green tea polyphenols, insulinlike growth factor I and glucose synchronously to maturation media can increase the intracellular glutathione concentration of oocytes after in vitro maturation, and improve the embryo development and blastocyst quality in bovine.

\section{Acknowledgements}

This research was supported by grants from Zhejiang Science and Technology Committee (Grant Agreement No.: 2008C02002-2; 2010C34009) and Zhejiang Province Natural Science Foundation (Grant Agreement No.: Y3100076).

\section{References}

FOULADI-NASHTA, A.A.; ALBERIO, R.; KAFI, M. et al. Differential staining combined with TUNEL labelling to detect apoptosis in preimplantation bovine embryos. Reproductive BioMedicine Online, v.10, p.497-502, 2005

GARDNER, D.K.; LANE, M.; SPITZER, A. et al. Enhanced rates of cleavage and development for sheep zygotes cultured to the blastocyst stage in vitro in the absence of serum and somatic cells: amino acids, vitamins, and culturing embryos in groups stimulate development. Biology of Reproduction, v.50, p.390-400, 1994.

HASHIMOTO, S.; MINAMI, N.; TAKAKURA, R. et al. Low oxygen tension during in vitro maturation is beneficial for supporting the subsequent development of bovine cumulus-oocyte complexes. Molecular Reproduction and Development, v.57, p.353-360, 2000a.

HASHIMOTO, S.; MINAMI, N.; YAMADA, M. et al. Excessive concentration of glucose during in vitro maturation impairs the developmental competence of bovine oocytes after in vitro fertilization: relevance to intracellular reactive oxygen species and glutathione contents. Molecular Reproduction and Development, v.56, p.520-526, 2000b.

HERRICK, J.R.; LANE, M.; GARDNER, D.K. et al. Metabolism, protein content and in vitro embryonic development of goat cumulus-oocyte complexes matured with physiological concentrations of glucose and L-lactate. Molecular Reproduction and Development, v.73, p.256-266, 2006.

HIGDON, J.V.; FREI, B. Tea catechins and polyphenols: health effects, metabolism and antioxidant functions. Critical Reviews in Food Science and Nutrition, v.43, p.89-143, 2003.

IWASAKI, S.; YOSHIBA, N.; USHIJIMA, H. et al. Morphology and proportion of inner cell mass of bovine blastocysts fertilized in vitro and in vivo. Journal of Reproduction and Fertility, v.90, p.279-284, 1990.

IWATA, H.; SHU, H.; OHOTA, M. et al. Effects of follicle size and electrolytes and glucose in maturation medium on nuclear maturation and developmental competence of bovine oocytes. Reproduction, v.127, p.159-164, 2004.

JONES, J.I.; CLEMMONS, D.R. Insulin-like growth factors and their binding proteins: biological actions. Endocrine Reviews, v.16, p.3-34, 1995.

KNIJIN, H.M.; GJORRET, J.O; VOS, P.L. et al. Consequences of in vivo development and subsequent culture on apoptosis, cell number, and blastocyst formation in bovine embryos. Biology of Reproduction, v.69, p.1371-1378, 2003.

KOO, D.B.; KANG, Y.K.; CHOI, Y.H. et al. Aberrant allocations of inner cell mass and trophectoderm cells in bovine nuclear transfer blastocysts. Biology of Reproduction, v.67, p.487-492, 2002.

LONERGAN, P.; FAIR, T. In vitro-produced bovine embryos-Dealing with the warts. Theriogenology, v.69, p.17-22, 2008.

PARRISH, J.J.; SUSKO-PARRISH, J.L.; LEIBFRIED-RUTLEDGE, M.L. et al. Bovine in vitro fertilization with frozen-thawed semen. Theriogenology, v.25, p.591-600, 1986.

PAWSHE, C.H.; RAO, K.B.; TOTEY, S.M. Effect of insulin-like growth factor I and its interaction with gonadotropins on in vitro maturation and embryonic development, cell proliferation, and biosynthetic activity of cumulus-oocyte complexes and granulosa cells in buffalo. Molecular Reproduction and Development, v.49, p.277-285, 1998. 
QUETGLAS, M.D.; COELHO, L.A.; GARCIA, J.M. et al. Effect of insulin-like growth factor-1 during in vitro oocyte maturation and in vitro culture of bovine embryos. Brazilian Journal of Veterinary and Animal Sciences, v.53, p.207-211, 2001.

RIZOS, D.; WARD, F.; DUFFY, P. et al. Consequences of bovine oocyte maturation, fertilization or early embryo development in vitro versus in vivo: implications for blastocyst yield and blastocyst quality. Molecular Reproduction and Development, v.61, p.234-248, 2002.

SCHROEDER, P.; KLOTZ, L.O.; SIES, H. Amphiphilic properties of (-)-epicatechin and their significance of protection of cells against peroxynitrite. Biochemical and Biophysical Research Communications, v.307, p.69-73, 2003.

SHORES, E.M.; PICTON, H.M.; HUNTER, M.G. Differential regulation of pig theca cell steroidogenesis by $\mathrm{LH}$, insulin-like growth factor I and granulosa cells in serum-free culture. Journal of Reproduction and Fertility, v.118, p.211-219, 2000.

SPINACI, M.; VOLPE, S.; De AMBROGI, M. et al. Effects of epigallocatechin-3- gallate (EGCG) on in vitro maturation and fertilization of porcine oocytes. Theriogenology, v.69, p.877-885, 2008.

STEFANELlO, J.R.; BARRETA, M.H.; PORCIUNCULA, P.M. et al. Effect of angiotensin II with follicle cells and insulin-like growth factor-I or insulin on bovine oocyte maturation and embryo development. Theriogenology, v.66, p.2068-2076, 2006.

TAKAHASHI, M.; NAGAI, T.; HAMANO, S. et al. Effect of thiol compounds on in vitro development and intracellular glutathione content of bovine embryos. Biology of Reproduction, v.49, p.228-232, 1993.

TERVIT, H.R.; WHITTINGHAM, D.G.; ROWSON, L.E. Successful culture in vitro of sheep and cattle ova. Journal of Reproduction and Fertility, v.30, p.493-497, 1972.

TIETZE, F. Enzymic method for quantitative determination of nanogram amounts of total and oxidized glutathione: applications to mammalian blood and other tissues. Analytical Biochemistry, v.27, p.502-522, 1969.

VAN SOOM, A.; YSEBAERT, M.T.; DE KRUIF, A. Relationship between timing of development, morula morphology, and cell allocation to inner cell mass and trophectoderm in in vitro-produced bovine embryos. Molecular Reproduction and Development, v.47, p.47-56, 1997

WANG, Z.G.; YU, S.D.; XU, Z.R. Improvement in bovine embryo production in vitro by treatment with green tea polyphenols during in vitro maturation of oocytes. Animal Reproduction Science, v.100, p.22-31, 2007.

WASIELAK, M.; BOGACKI, M. Apoptosis inhibition by insulin-like growth factor (IGF)-I during in vitro maturation of bovine oocytes. Journal of Reproduction and Development, v.53, p.419-426, 2007.

WONGSRIKEAO, P.; OTOI, T.; TANIGUCHI, M. et al. Effects of hexoses on in vitro oocyte maturation and embryo development in pigs. Theriogenology, v.65, p.332-343, 2006.

YAVARI, M.; NAOI, H.; KAEDEI, Y. et al. Effects of epigallocatechin3 -gallate on the developmental competence of parthenogenetic embryos in the pig. Italian Journal of Animal Science, v.9, p.386-389, 2010. 